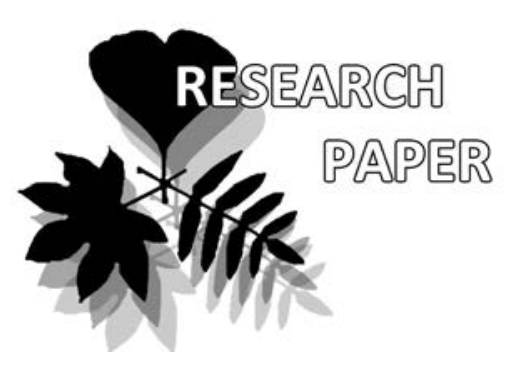

\title{
Mycolith (fungal phytolith) morphotypes and biosilification of proteins in wood-destroying and pileate fungi
}

Kirill S. Golokhvast ${ }^{1,2 *}$, Ivan V. Seryodkin ${ }^{1,2}$, Eugenia M. Bulakh ${ }^{3}$, V.V. Chaika ${ }^{1}$, A.M. Zakharenko ${ }^{1}$, A.S. Kholodov' ${ }^{1}$ I.E. Pamirsky ${ }^{1}$ \& G. Chung ${ }^{4}$

Kirill S. Golokhvast ${ }^{1,2 *}$

e-mail: golokhvast.ks@dvfu.ru

Ivan V. Seryodkin ${ }^{1,2}$

e-mail: seryodkinivan@inbox.ru

Eugenia M. Bulakh ${ }^{3}$

e-mail: bulakh@ibss.dvo.ru

V.V. Chaika ${ }^{1}$

e-mail: chaika.vv@dvfu.ru

A.M. Zakharenko ${ }^{1}$

e-mail: zakharenko.am@dvfu.ru

A.S. Kholodov ${ }^{1}$

e-mail: kholodov.as@dvfu.ru

I.E. Pamirsky ${ }^{1}$

e-mail: pamirskii.ie@students.dvfu.ru

G. Chung $4 *$

e-mail: chung@chonnam.ac.kr

${ }^{1}$ Engineering School, Far Eastern Federal University, Vladivostok, Russia

2 Pacific Geographical Institute FEB RAS, Vladivostok, Russia

${ }^{3}$ Federal Scientific Center for the East Asia Terrestrial Biodiversity FEB RAS,

Vladivostok, Russia

${ }^{4}$ Department of Biotechnology, Chonnam National University, Chonnam, Republic of Korea

* corresponding authors

Manuscript received: 08.11.2017

Review completed: 26.11.2017

Accepted for publication: 21.03.2018

Published online: 11.04.2018

\begin{abstract}
A B S T R A C T
The process of biomineralization in fungi is discussed for the first time. The results of a comprehensive study of fungal phytoliths (mycoliths) using optical microscopy and RAMAN spectroscopy are presented. The RAMAN spectrum contains bands of crystalline silicon dioxide and amorphous silica. In all types of fungi and trees examined, two morphotypes of phytolite particles were identified with an aid of microscope, oblong and spherical. The rest of the particles were considered formless. To explain the mechanisms of biosilification, a bioinomatic analysis of biosilicon proteins homologues (silicateins, silacidins, silaffins, silicon transporters, silicase) in annotated fungal proteomes was carried out by in silico technique. The paper shows proteins of fungi, which can potentially participate in the formation of mycoliths.
\end{abstract}

K e y w o r d s : fungi, mycolith, phytolith, biomineralization proteins

\section{P E 3 Ю M E}

Голохваст К.С., Середкин И.В., Булах Е.М., Чайка В.В., Захаренко А.М., Холодов А.С., Памирский И.Е., Чунг Ж. Морфотипы миколитов (грибных фитолитов) и биосилификация белков в грибах, разрушающих древесину. Впервые комплексно обсужАается процесс биоминерализации у грибов. Приводятся результаты комплексного изучения фитолитов грибов (миколитов) методами оптической микроскопии и RAMAN-спектроскопии. RAMAN-спектр содержит полосы кристалАического Аиоксида кремния и аморфного кремнезема. Во всех видах исследованных грибов и деревьев микроскопически установ ены два морфотипа частиц фитолитов: продолговатые и шарообразные. Остальные частицы были бесформенные. Аля объяснения механизмов был произведен биоинофрмационный анализ гомологов белков биосилификации (силикатеинов, силацидинов, силаффинов, транспортеров кремния, силиказы) в аннотированных протеомах грибов методом in silico. В работе показаны белки грибов, которые могут потенциально участвовать в процессе формирования миколитов.

КАючевые слова: грибы, миколиты, фитолиты, биоминерализующие белки
Phytoliths are not organic fossil micrometric minerals deposited in situ, and therefore track mainly local changes in vegetation composition. Their structures are resulting from the accumulation of oxalate, carbonate, or silica in cell wall or entire cell. In recent years, phytolith analysis has became valuable tool in taxonomic, palaeoenvironmental and archaeological work to determine the presence of species in a sample (Piperno 2006, Katz et al. 2015, Zurro et al. 2016). Phytoliths have been found in many plant groups (Madella et al. 2005, Piperno 2006), as biogenic silica is deposited in some of tissues. The differing roles of silicon microformations in plants are not completely understood.
The microbial metabolism of silicon has been limited, except on diatoms and plants. Wainwright et al. (1997) suggested that fungi might utilize silicon compounds as an energy source. Kaiser \& Benz (1998) reported on the beneficial effects of silicon on growth of some fungi such as Fusarium spp. and Verticillium spp. Therefore, the silica might be deposited in fungus cells to develop fungal phytoliths (mycoliths). Fungi, unlike plants, are characterized by heterotrophic type of the nourishment. They contain a large set of enzymes used to destruction of the substratum and extract from it nutrients. The mycelium and fruiting bodies accumulate a complex of organic compounds, inclu- 
ding nucleic acids, proteins, and lipids, among others. The content and composition of the elements in fungi depends on the nature of the substrate, fungal species, and age of fruiting bodies.

In our previous studies, we evaluated that phytoliths in red multicellular algae Chondrus crispus contains proteins similarly to the biosilicification proteins in sponges, diatoms, and higher plants (Golokhvast et al. 2014, Golokhvast et al. 2015). From our best knowledge, there is no report on phytoliths in fungi. Therefore, to understand of the biological role of phytoliths and their evolutionary origin, we investigated phytoliths in another ancient taxon, the kingdom Fungi.

\section{MATERIAL AND METHODS}

\section{Sample collection}

In order to study mycoliths in fungi, samples of fungi and the wood infected by wood-destroying fungi were collected in Primorsky Region (the Russian Far East) in 2014. Fruiting bodies of seven species of pileate fungi (Russula deleca Fr., Melanoleuca grammopodia (Bull.) Murrill, Lactarius vellereus (Fr.) Fr., Kuehneromyces mutabilis (Schaeff.) Singer \& A.H. Sm., Hygrophorus hedrychii (Velen.) K. Kult, Lycoperdon perlatum Pers., Lactarius helvus (Fr.) Fr.) were collected from five host species of plants (Larix cajanderi, Quercus mongolica, Alnus hirsuta, Betula platyphylla, and Salix sp.) from the mixed coniferous-deciduous forest on the Muravyov-Amursky Peninsula (near Vladivostok) $[\mathrm{n}=7$ fungi $\times 5$ plants $=35]$. Fruiting bodies of 12 species of wood-destroying fungi (Panus neostrigosus Drechsler-Santos \& Wartchow, Fomes fomentarius (L.) Fr., Laetiporus montanus Černý ex Tomšovský \& Jankovský, Pleurotus citrinopileatus Singer, P. pulmonarius (Fr.) Quél., Rhodofomes cajanderi (P. Karst.) B.K. Cui, M.L. Han \& Y.C. Dai, Fomitopsis pinicola (Sw.) P. Karst., Mycorrhaphium adustum (Schwein.) Maas Geest., Trametes versicolor (L.) Lloyd, Ganoderma applanatum (Pers.) Pat., Stereum ostrea (L.) Lloyd, Trichaptum biforme (Fr.) Ryvarden) were collected from five host plants species (Larix cajanderi, Quercus mongolica, Alnus birsuta, Betula platyphylla, and Salix sp.) from coniferous-deciduous forests of the Middle Sikhote-Alin (basins of rivers Serebryanka, Tayozhnaya, and Kolumbe) [n $=12$ fungi $\times$ 5 plants $=60]$. Samples of bark and wood were collected separately from each tree species.

\section{Sample preparation}

Mycoliths were extracted using the method described by Piperno (2006) with some modifications. For this, the fruiting bodies of fungi and wood tissues (approximately $30-50 \mathrm{~g}$ ) were washed with distilled water and then burned in enameled ceramic pots covered with lids in a muffle furnace at ambient atmosphere for $4 \mathrm{~h}$ at $450^{\circ} \mathrm{C}$. The ash was placed into the plastic tubes and washed successively with a solution of $10 \%$ hydrochloric acid and concentrated nitric acid (JSC "Neva-Reactiv", Saint Petersburg, Russia). Next, $10 \mathrm{ml}$ of the liquid incubated for $20 \mathrm{~min}$. with occasional gentle shaking of the tube. The samples were repeatedly washed with $10 \mathrm{ml}$ distilled water. After the final wash, $0.5 \mathrm{ml}$ of the mixture was decanted as prepared samples for microscopic examination.

\section{Optical microscopy}

Mycoliths were observed using the optical microscope Axio Imager 2 (Zeiss, Oberkochen, Germany) with a digital camera AxioCam 3 (Zeiss) at 100-630 X magnification. Glass slides and cover glasses (JSC BioVitrum) were used. The length and width of the visible image of each particle were measured using Axio Vision 4.2 program (Zeiss) included in the optical microscope software. In shapeless formations, the narrowest portion was considered to be the width. The measurement was conducted using two-dimensional images.

\section{Raman spectroscopy}

The spectra were obtained on a Raman-spectrometer RNX1 (Kaiser Optical Systems, Dresden, Germany) combined with an optical microscope Morphologi G3-ID (Malvern, UK). Prepared samples were placed on silvered surface. At 50-fold amplification, we used laser excitation at $785 \mathrm{~nm}$. Next, the laser exposure of was $1 \mathrm{~s}$ and accumulation amount were 50. The laser was used in high-power mode, which corresponds to approximately $16 \mathrm{mV}$ in the configuration of devices (Saggu et al. 2015).

\section{Silicon transporters screening}

The search for typical representatives of silicon transporters, aquaporins, silaffins, silicateins, silacidins, and silicase (peptides and proteins of diatoms, sponges, rice, and corn were chosen) in the nucleotide sequence was conducted using BLAST (http://blast.ncbi.nlm.nih.gov) as described previously (Pamirsky \& Golokhvast 2013, Golokhvast et al. 2014). From the Uniprot database (March-April 2016), we obtained the amino acid sequences of silicon transporters (ID O81199 and C7G3B4), aquaporin (ID Q6Z2T3), silaffin (ID Q9SE35), and silicateins (ID B5B2Z1, B1GSK9, and B5LT52). The silacidins sequences were obtained from Richthammer et al. (2011) while those from silicase were from Schröder et al. (2007).

\section{RESULTS AND DISCUSSION}

The phytoliths content is affected by many environmental factors such as climate, location, time collection, management practices (Ball et al. 2016, Hodson 2016). Thus, we collected different fungi growing on the same wood and the same fungi on different woods to minimize the influence of these factors. After collecting, the phytolith extracted from the fungi and wood samples and the morphotypes of those phytoliths was showed in Appendix 1. The oblong and spherical morphotypes of mycoliths were detected in the samples of pileate and wood-destroying fungi (Fig. 1, Appendix 1). The spherical phytoliths were only not found in some species of pileate fungi such as $M$. grammopodia, L. vellereus, and $\mathrm{H}$. hedrichii and P. citrinopileatus wood-destroying fungi. Thus, with a few exceptions, we hypothesized that oblong and spherical mycoliths are characteristic to fungi, particularly for pileate and wood-destroying fungi. The remaining particles were shapeless (Fig. 1C, Appendix 1). It was similar to the fragments of larger particles.

The size and frequency of mycoliths found in the wood was comparable (Table 1, Appendix 1). In general, there 


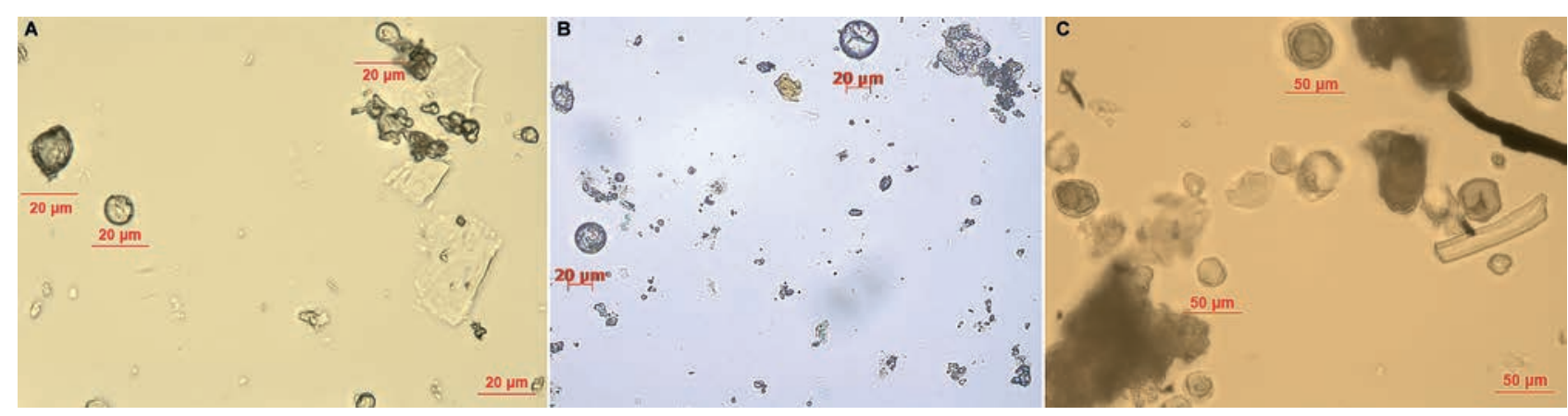

Figure 1 Typical form of mycoliths found by optical microscopy in the pileate fungus Pleurotus pulmonarius (A); the wood-destroying fungus Ganoderma applanatum (B); the wood of Larix dahurica (C)

was no significant difference of oblong and spherical mycoliths size among pileate and wood-destroying fungi growing on the wood. This indicates that the shape of mycoliths is a typical characteristic of the fungus that is genetically unchanged and is not affected by environment factors. Previous studies also showed that phytolith morphology depends only on cell shape and elongation (Sørensen et al. 2008, Rudall et al. 2014).

The frequency of spherical mycoliths in pileate and wood-destroyed fungi were $2.67-44 \%$ and $0.8-16 \%$ respectively. These results showed higher frequency of oblong mycoliths than spherical mycoliths in both fungi.

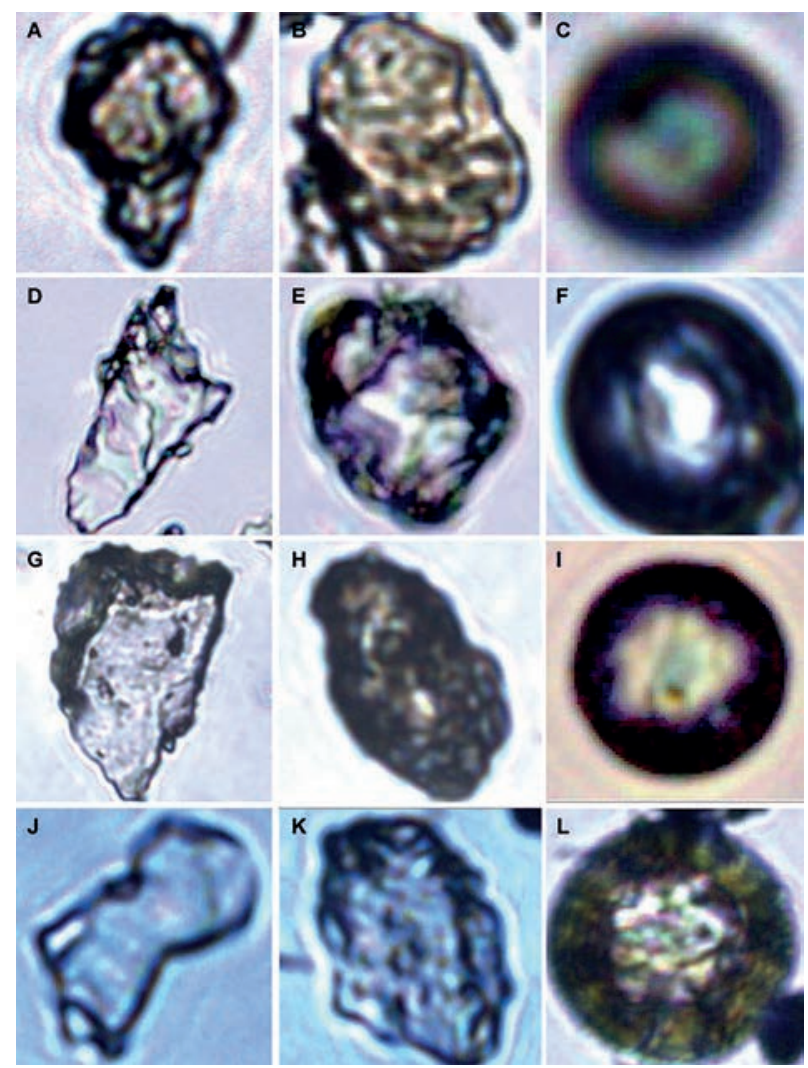

Figure 2 Morphotypes of mycoliths (left column - shapeless, central - oblong and right - spherical) in fungus Fomes fomentarius collected on wood of dead Abies nephrolepis (A-C), dead Alnus birsuta (D-F), alive Betula davurica ( $\mathrm{G}-\mathrm{I})$, dead Betula platyphylla $(\mathrm{J}-\mathrm{L})$ (the scale is not kept)
Moreover, the variety of frequency and size of mycoliths in different fungi samples leading to the dimensions of mycoliths can be considered a diagnostic feature for establishment distinguish between species of fungi.

To determine the effect of location on morphotypes of mycoliths, we compared the size of mycoliths in Fomes fomentarius from different woods (Fig 2). However, correlation analysis showed no correlation between the dimensions of particles in fungi and wood on which these samples grow (Table 2).

Raman spectroscopy revealed that the chemical composition of all studied mineral particles was silicon dioxide $\left(\mathrm{SiO}_{2} \mathrm{nH}_{2} \mathrm{O}\right.$, Fig. 3). The spectra showed a $476 \mathrm{~cm}^{-1}$ band for amorphous silica and $514 \mathrm{~cm}^{-1}$ band for crystalline silicon dioxide. Most particles are colorless and had varying degrees of transparency. We also found particles that were yellowish color. The traces of inorganic sulfates and organic were found at some particles.

In our best knowledge, there is no information regarding the availability of biosilification proteins in fungi (except for silicon transporters) in the electronic genome and proteome databases or in the literature. To identify a gene family involved in mycoliths formation. We searched the homologs of the primary structure of biosilification proteins in silico across the fungi section (Table 3). A low or unreliable degree of homology in polypeptide sections with lengths of 3-6 to 10-150 amino acid residues was for all proteins. In detail, proteins are annotated in the database

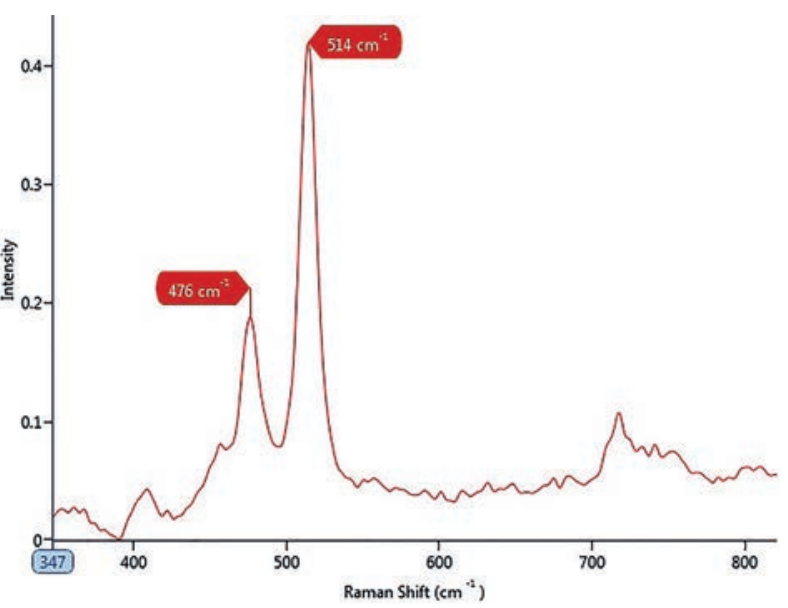

Figure 3 Raman spectrum of a spherical mycolith 
Golokhvast et al.

Table 1 . The average sizes $(\mu \mathrm{m})$ and the frequency $(\%)$ of phytoliths in fungi and wood

\begin{tabular}{|c|c|c|c|}
\hline & Shapeless & Oblong & Spherical \\
\hline \multirow[t]{2}{*}{ Pileate fungi } & ${ }^{1} \mathrm{~W}: \quad 12.42 \pm 3.004$ & W: $\quad 14.41 \pm 3.696$ & ${ }^{3} \mathrm{~d}: \quad 11.63 \pm 4.178$ \\
\hline & $\begin{aligned}{ }^{2} \mathrm{~L}: & 16.05 \pm 3.871 \\
\text { Content: } & 52.97 \pm 18.627^{\mathrm{a}}\end{aligned}$ & $\begin{aligned} \text { L: } & 18.52 \pm 4.688 \\
\text { Content: } & 42.58 \pm 14.202^{\mathrm{a}}\end{aligned}$ & Content: $13.53+17.438$ \\
\hline \multirow{3}{*}{$\begin{array}{l}\text { Wood- } \\
\text { destroying } \\
\text { fungi }\end{array}$} & $\mathrm{W}: \quad 13.78 \pm 2.404$ & W: $15.45 \pm 3.145$ & $\mathrm{~d}: \quad 13.66 \pm 2.898$ \\
\hline & $\mathrm{L}: \quad 17.66 \pm 3.009$ & L: $\quad 20.45 \pm 3.615$ & \\
\hline & Content: $44.72+8.907^{a}$ & Content: $48.77+8.976^{a}$ & Content: $8.16 \pm 5.260^{\mathrm{b}}$ \\
\hline \multirow[t]{2}{*}{ Bark } & $\begin{array}{cc}\text { W: } & 11.15 \pm 2.195 \\
\mathrm{~L}: & 14.08 \pm 2.632\end{array}$ & $\begin{array}{cc}\text { W: } & 12.56 \pm 3.067 \\
\mathrm{~L}: & 15.95 \pm 4.082\end{array}$ & d: $12.10 \pm 4.992$ \\
\hline & Content: $\quad 50.21 \pm 6.203^{\mathrm{a}}$ & Content: $\quad 42.55 \pm 3.96^{a}$ & Content: $7.24 \pm 6.106^{\mathrm{b}}$ \\
\hline \multirow[t]{2}{*}{ Wood } & $\begin{array}{cc}\text { W: } & 14.81 \pm 4.149 \\
\mathrm{~L}: & 18.51 \pm 5.818\end{array}$ & $\begin{array}{cc}\text { W: } & 19.90 \pm 6.200 \\
\mathrm{~L}: & 23.75 \pm 8.214\end{array}$ & $18.70 \pm 5.347$ \\
\hline & Content: $\quad 41.58+11.075^{\mathrm{a}}$ & Content: $49.39+9.676^{\mathrm{a}}$ & Content: $9.01 \pm 6.001^{\mathrm{b}}$ \\
\hline
\end{tabular}

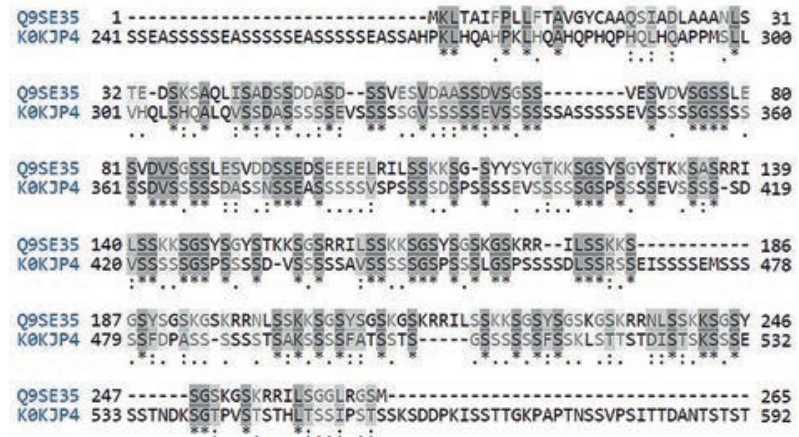

Figure 4 Example of alignment of polypeptide sections of sillafins of sponge Cylindrotheca fusiformis (Q9SE35) and unknown protein of higher fungi Wickerbamomyces ciferrii (K0KJP4). Asterisk indicates identical Am
Table 3. Correlation analysis of mycolith/phytolith dimensions in fungi and trees

\begin{tabular}{|l|l|l|l|}
\hline \multirow{2}{*}{ Fungi / Tree } & \multicolumn{3}{|c|}{ Parameters } \\
\cline { 2 - 4 } & & width & length \\
\hline \multirow{2}{*}{ F. fomentarius / A. hirsuta } & width & -0.59208 & -0.61523 \\
\cline { 2 - 4 } & length & -0.59563 & -0.62624 \\
\hline \multirow{2}{*}{ F. fomentarius / B. platyphylla } & width & -1 & -1 \\
\cline { 2 - 4 } & length & -1 & -1 \\
\hline \multirow{2}{*}{ T. biforme / B. platyphylla } & width & -1 & -1 \\
\cline { 2 - 4 } & length & -1 & -1 \\
\hline
\end{tabular}

Table 3. Homologs of biosilification proteins in fungi proteomes

\begin{tabular}{|c|c|c|c|c|c|}
\hline $\begin{array}{l}\text { Biosilification } \\
\text { protein }\end{array}$ & ID & $\begin{array}{l}\text { Number of } \\
\text { homologues }\end{array}$ & $\begin{array}{l}\text { Taxonomic distribution of } \\
\text { homologues }\end{array}$ & $\begin{array}{l}\text { Degree of } \\
\text { homology }(\%)\end{array}$ & E-value \\
\hline Silacidin A & ACL00587 & $250^{*}$ & $\begin{array}{l}\text { Dikarya }-238 \\
\text { Mucorales }-8 \\
\text { Rhizophagus - } 4 \\
\end{array}$ & $42.9-80.0$ & $1 \mathrm{E}^{-6}-6.6 \mathrm{E}^{-2}$ \\
\hline Silaffin & Q9SE35 & $250^{*}$ & $\begin{array}{l}\text { Dikarya }-241 \\
\text { Mucorales }-8 \\
\text { Nematocida }-1\end{array}$ & $27.0-39.0$ & $41 \mathrm{E}^{-18}-17 \mathrm{E}^{-12}$ \\
\hline Silicase & CAI43319 & 98 & $\begin{array}{l}\text { Dikarya - } 91 \\
\text { Rhirophagus }-6 \\
\text { Batrachochytrium - } 1\end{array}$ & $22.8-29.8$ & $2.1 \mathrm{E}^{-9}-7.9 \mathrm{E}^{-2}$ \\
\hline Silicatein & B5LT52 & 15 & $\begin{array}{l}\text { Dikarya }-12 \\
\text { Mortierella }-1\end{array}$ & $20.7-52.7$ & $1.2 \mathrm{E}^{-70}-8.6 \mathrm{E}^{-2}$ \\
\hline Silicatein & B1GSK9 & 12 & $\begin{array}{l}\text { Dikarya-11 } \\
\text { Mortierella }-1 \\
\end{array}$ & $24.5-48.4$ & $7.5 \mathrm{E}^{-70}-8.9 \mathrm{E}^{-2}$ \\
\hline Silicatein & B5B2Z1 & 7 & $\begin{array}{l}\text { Mortierella }-1 \\
\text { Saccharomyces }-6\end{array}$ & $24.8-52.2$ & $5.1 \mathrm{E}^{-71}-8.7 \mathrm{E}^{-2}$ \\
\hline Silicon transporter & O81199 & 21 & $\begin{array}{l}\text { Dikarya }-11 \\
\text { Apansporoblastina }-2 \\
\text { Early diverging fungal lineages }-3 \\
\text { Rozella }-1\end{array}$ & $25.3-32.5$ & $0.16-9.5$ \\
\hline Silicon transporter & C7G3B4 & $250^{*}$ & $\begin{array}{l}\text { Dikarya }-234 \\
\text { Mucorales }-14 \\
\text { Rbirophagus }-2 \\
\end{array}$ & $18.4-31.5$ & $2.40 \mathrm{E}^{-22}-2.7 \mathrm{E}^{-9}$ \\
\hline Aquaporin NIP2-1 & Q6Z2T3 & $250^{*}$ & $\begin{array}{l}\text { Dikarya-226 } \\
\text { Mitosporidium - } 1 \\
\text { Mucorales }-17 \\
\text { Rhizophagus - } 6\end{array}$ & $25.3-33.8$ & $9.40 \mathrm{E}^{-29}-4.4 \mathrm{E}^{-19}$ \\
\hline
\end{tabular}


for pileate mushrooms: 58 - for P. pulmonarius, 8 - M. grammopodia, 5 - for L. vellereus, 1 - for L. perlatum, and 2 - for $L$. helvus. Proteins are annotated in the database for wooddestroying fungi: 27 - for F. fomentarius, 7 - for P. citrinopileatus, 2 - for F. cajanderi, 13,862 - for F. pinicola, 2 - for M. adustum, 1205 - for T. versicolor, 24 - for G. applanatum, 1for S. ostrea, and 2 - for T. biforme. There are no data for the remaining fungi. Most of homologs are still either unknown or irrelevant to biosilification. Among of homologs, the potential K0KPL4 identifed from Wickerhamomyces ciferrii was similar silaffin protein in diatom Cylindrotheca fusiformis, suggests that suggests their participation in biosilification as a substrate for biosilicon deposition (Fig. 4). This sequence information will help us to isolate the Si transporter gene in fungi in future study.

\section{CONCLUSIONS}

This article offers the first elaborate description of mycoliths, which are probably formed due to the existence of proteins that are known to be involved in fungi silicon uptake. The main oblong, spherical phytoliths and their structures was identified in 7 pileate fungi and 12 wooddestroying fungi collected from different regions in a coniferous-deciduous forest in Russia. The variety of size and content of mycoliths among species of fungi could be used as a reliable tool to separate pileate and wood-destroying fungi. To our knowledge, the silicon uptake mechanism has not yet been found in any fungi. This process and its gene relation to biosilicification of fungi will be considered in future works.

\section{ACKNOWLEDGEMENTS}

The project was supported by the Russian Foundation for Basic Research (15-04-02979).

\section{LITERATURE CITED}

Ball, T., K. Chandler-Ezell, R. Dickau, N. Duncan, T.C. Hart, J. Iriarte, C. Lentfer, A. Logan, H. Lu \& M. Madella 2016. Phytoliths as a tool for investigations of agricultural origins and dispersals around the world. Journal of Archaeological Science 68: 32-45.

Golokhvast, K.S., O.R. Kudryavkina, A.M. Zakharenko, V.V. Chaika, A. Kholodov, I.V. Seryodkin, A.A. Sergievich \& A.A. Karabtsov 2015. Phytolithes (SiO microparticles) of some multicellular brown algae. Der Pharma Chemica 7: 307-311.
Golokhvast, K.S., I.V. Seryodkin, V.V. Chaika, A.M. Zakharenko \& I.E. Pamirsky 2014. Phytoliths in taxonomy of phylogenetic domains of plants. BioMed research international 4: 648326.

Hodson, M.J. 2016. The development of phytoliths in plants and its influence on their chemistry and isotopic composition. Implications for palaeoecology and archaeology. Journal of Archaeological Science 68:62-69.

Kaiser, T. \& K.W. Benz 1998. Floating-zone growth of silicon in magnetic fields. III. Numerical simulation. Journal of Crystal Growth 183:564-572.

Katz, O., S. Lev-Yadun \& P. Bar 2015. Plant silicon and phytolith contents as affected by water availability and herbivory: integrating laboratory experimentation and natural habitat studies. Silicon. P. 1-3. DOI: 10.1007\%2Fs12633015-9310-y

Madella, M., A. Alexandré \& T. Ball 2005. International code for phytolith nomenclature 1.0. Annals of Botany 96:253-260.

Piperno, D.R. 2006. Phytoliths: a comprehensive guide for archaeologists and paleoecologists. Altamira Press, Latham, 238 pp.

Richthammer, P., M. Börmel, E. Brunner \& K.H. van Pée 2011. Biomineralization in diatoms: The role of silacidins. ChemBioChem 12:1362-1366.

Rudall, P.J., C.J. Prychid \& T. Gregory 2014. Epidermal patterning and silica phytoliths in grasses: an evolutionary history. The Botanical Review 80:59-71.

Saggu, M., J. Liu \& A. Patel 2015. Identification of subvisible particles in biopharmaceutical formulations using Raman spectroscopy provides insight into polysorbate 20 degradation pathway. Pharmacentical Research 32:2877-2888.

Schröder, H.C., A. Krasko, D. Brandt, M. Wiens, M.N. Tahir, W. Tremel \& W.E.G. Müller 2007. Silicateins, silicase and spicule-associated proteins: synthesis of demosponge silica skeleton and nanobiotechnological applications. In: Porifera Research: Biodiversity, Innovation and Sustainability (M.R. Custodio, G. L'obo-Hajdu, E. Hajdu \& D. Muricy, eds), pp. 581-592, Museu Nacional, Rio de Janeiro.

Sørensen, I., F.A. Pettolino, S.M. Wilson, M.S. Doblin, B. Johansen, A. Bacic \& W.G.T. Willats 2008. Mixed-linkage $(1 \rightarrow 3),(1 \rightarrow 4)-\beta$-d-glucan is not unique to the Poales and is an abundant component of Equisetum arvense cell walls. The Plant Journal 54: 510-521.

Wainwright, M., K. Al-Wajeeh \& S.J. Grayston 1997. Effect of silicic acid and other silicon compounds on fungal growth in oligotrophic and nutrient-rich media. Mycological Research 101:933-938.

Zurro, D., J.J. García-Granero, C. Lancelotti \& M. Madella 2016. Directions in current and future phytolith research. Journal of Archaeological Science 68:112-117. 


\section{APPENDICES}

Appendix 1. Morphotypes of phytoliths in fungi and trees. The scale is not kept

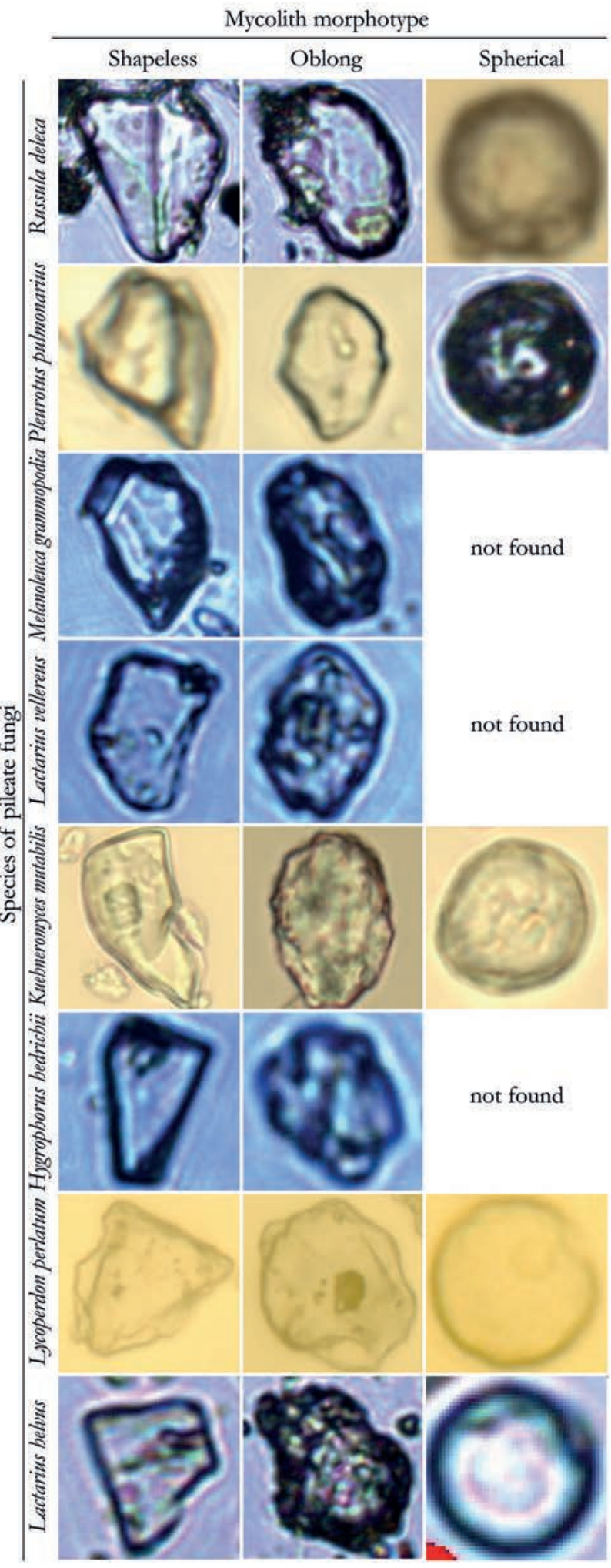

Figure A1 Morphotypes of mycoliths in pileate fungi

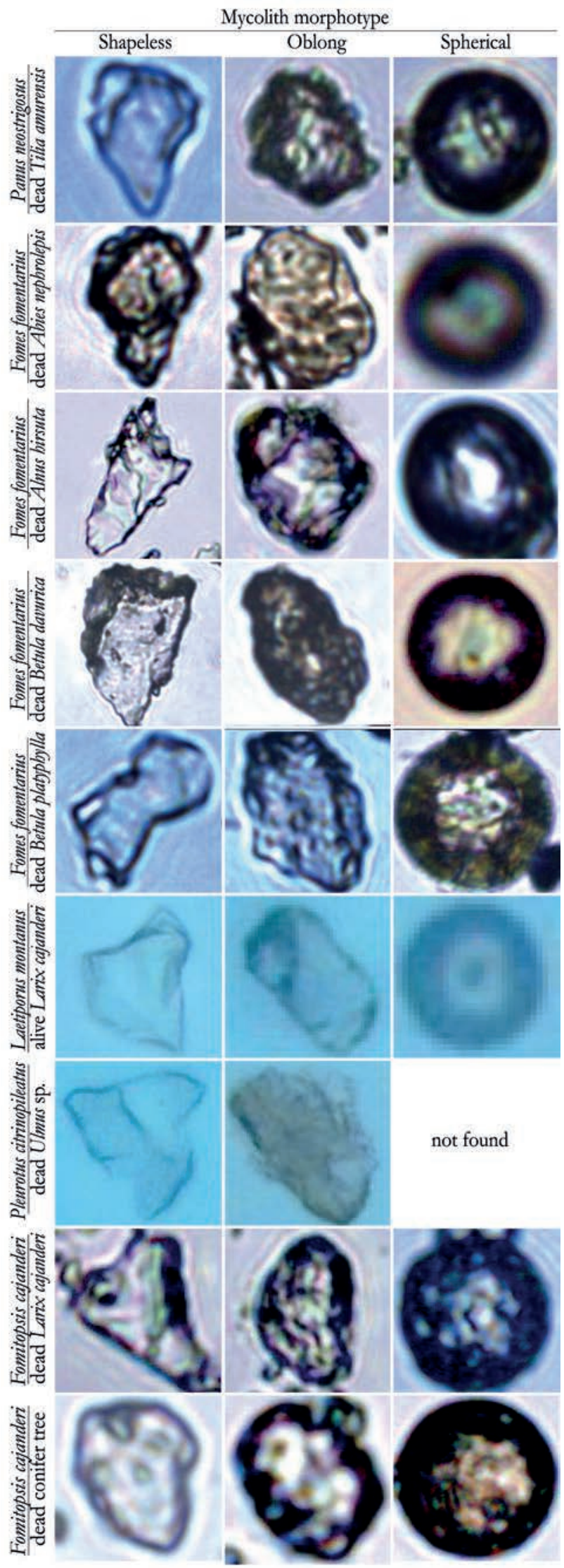

Figure A2 Morphotypes of mycoliths in wood-destroying fungi (name of fungus above, and tree below line) 


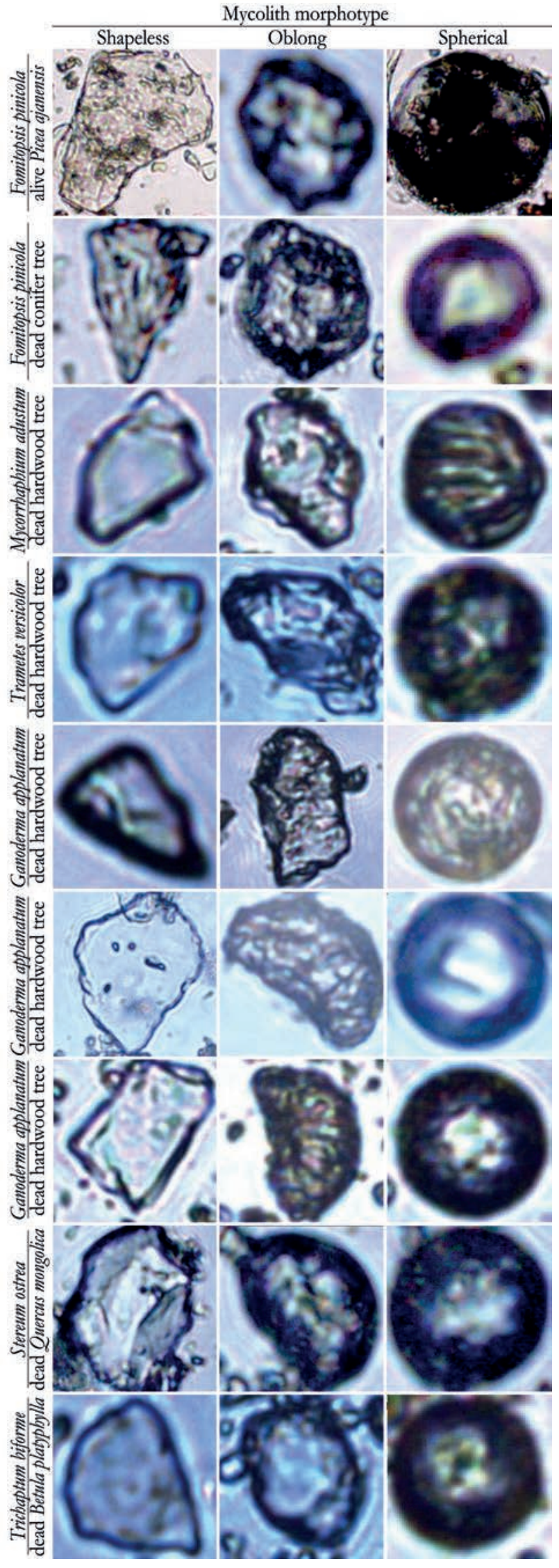

Figure A3 Morphotypes of mycoliths in wood-destroying fungi (name of fungus above, and tree below line)

Figure A4 Morphotypes of phytoliths in wood and bark of tree species
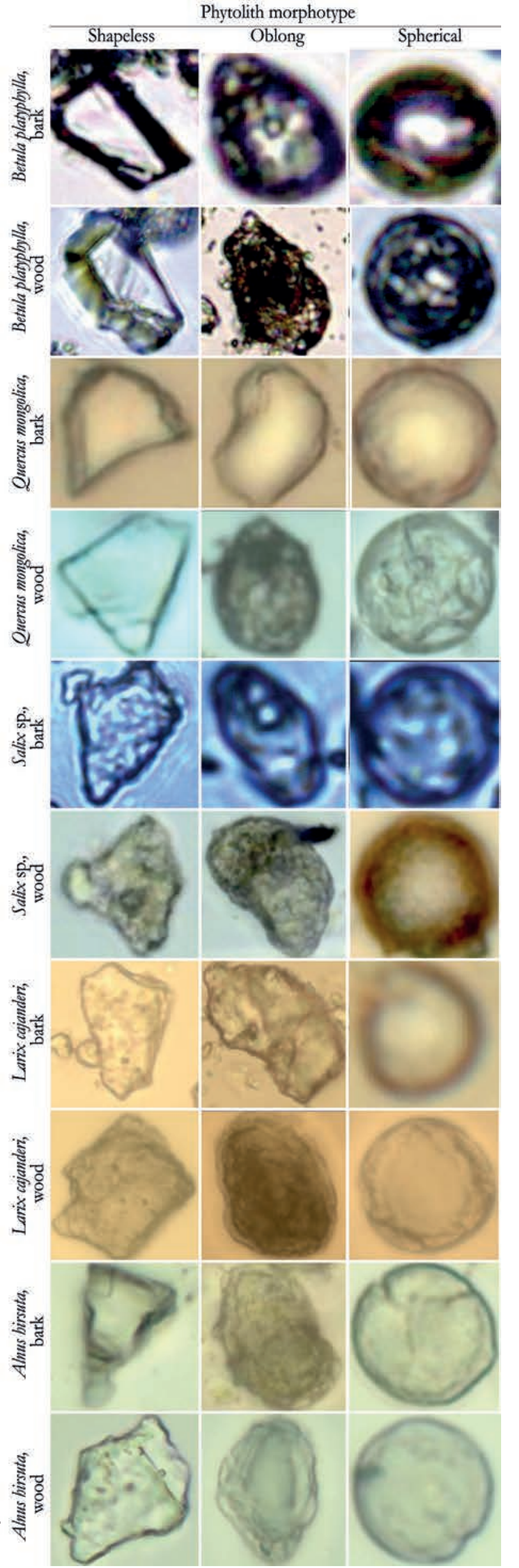
Golokhvast et al.

Appendix 2. Sizes $(\mu \mathrm{m})$ and the content (\%) of phytoliths in fungi and wood

\begin{tabular}{|c|c|c|c|}
\hline \multirow[t]{2}{*}{ Species of fungus or tree } & \multicolumn{3}{|c|}{ Morphotype of phytoliths } \\
\hline & Shapeless & Oblong & Spherical \\
\hline \multicolumn{4}{|l|}{ Pileate fungi } \\
\hline Russula deleca & $\begin{array}{l}\text { W: } 9.26 \pm 4.96 \text {; L: } 11.89 \pm 5.38 \\
\text { Content } 58\end{array}$ & $\begin{array}{l}\text { W: } 10.69 \pm 5.61 ; \mathrm{L}: 14.2 \pm 6.97 \\
\text { Content } 39\end{array}$ & $\begin{array}{l}\text { Diameter } 6.28 \pm 3.02 \\
\text { Content } 3\end{array}$ \\
\hline Pleurotus pulmonarius & $\begin{array}{l}\text { W: } 7.4 \pm 4.25 ; \mathrm{L}: 9.67 \pm 5.69 \\
\text { Content } 96\end{array}$ & $\begin{array}{l}\text { W: } 10.92 \pm 5.89 ; \text { L: } 14.32 \pm 6.68 \\
\text { Content } 33.33\end{array}$ & $\begin{array}{l}\text { Diameter } 15.29 \pm 2.96 \\
\text { Content } 2.67\end{array}$ \\
\hline Melanoleuca grammopodia & $\begin{array}{l}\text { W: } 16.98 \pm 11.94 ; \text { L: } 22.17 \pm 14.07 \\
\text { Content } 41.33\end{array}$ & $\begin{array}{l}\text { W: } 21.11 \pm 10.6 ; \text { L: } 27.72 \pm 13.82 \\
\text { Content } 58.66\end{array}$ & Not found \\
\hline Lactarius vellereus & $\begin{array}{l}\text { W: } 11.97 \pm 6.38 ; \text { L: } 15.15 \pm 6.81 \\
\text { Content } 39\end{array}$ & $\begin{array}{l}\text { W: } 12.43 \pm 5.18 ; \mathrm{L}: 15.63 \pm 6.33 \\
\text { Content } 61\end{array}$ & Not found \\
\hline Kuehneromyces mutabilis & $\begin{array}{l}\text { W: } 13.34 \pm 4.29 ; \mathrm{L}: 17.23 \pm 5.47 \\
\text { Content } 51.33\end{array}$ & $\begin{array}{l}\text { W: } 16.82 \pm 6 ; \text { L: } 21.02 \pm 6.82 \\
\text { Content } 42.67\end{array}$ & $\begin{array}{l}\text { Diameter } 13.87 \pm 4.34 \\
\text { Content } 6\end{array}$ \\
\hline Hygrophorus bedrichii & $\begin{array}{l}\text { W: } 13.06 \pm 6.69 ; \text { L: } 16.78 \pm 8.81 \\
\text { Content } 51.33\end{array}$ & $\begin{array}{l}\text { W: } 13.07 \pm 4.87 \text {; L: } 16.98 \pm 6.03 \\
\text { Content } 48.67\end{array}$ & Not found \\
\hline Lycoperdon perlatum & $\begin{array}{l}\text { W: } 12.54 \pm 5.93 ; \mathrm{L}: 17.11 \pm 8.55 \\
\text { Content } 39.4\end{array}$ & $\begin{array}{l}\text { W: } 12.67 \pm 4.24 ; \mathrm{L}: 16.4 \pm 4.8 \\
\text { Content } 16.6\end{array}$ & $\begin{array}{l}\text { Diameter } 7.99 \pm 2.57 \\
\text { Content } 44\end{array}$ \\
\hline Lactarius belvus & $\begin{array}{l}\text { W: } 14.81 \pm 5.48 ; \mathrm{L}: 18.41 \pm 6.2 \\
\text { Content } 47.33\end{array}$ & $\begin{array}{l}\text { W: } 17.60 \pm 5.05 ; \mathrm{L}: 21.90 \pm 6.01 \\
\text { Content } 40.67\end{array}$ & $\begin{array}{l}\text { Diameter } 14.72 \pm 6.62 \\
\text { Content } 12\end{array}$ \\
\hline \multicolumn{4}{|l|}{ Wood-destroying fungi } \\
\hline Panus neostrigosus & $\begin{array}{l}\text { W: } 16.17 \pm 7.79 ; \text { L: } 21.47 \pm 12.57 \\
\text { Content } 34\end{array}$ & $\begin{array}{l}\text { W: } 23.42 \pm 14.22 ; \mathrm{L}: 28.80 \pm 16.81 \\
\text { Content } 58\end{array}$ & $\begin{array}{l}\text { Diameter } 17.38 \pm 4.67 \\
\text { Content } 8\end{array}$ \\
\hline Fomes fomentarius & $\begin{array}{l}\text { W: } 12.23 \pm 4.87 ; \mathrm{L}: 15.66 \pm 6.08 \\
\text { Content } 48\end{array}$ & $\begin{array}{l}\text { W: } 13.63 \pm 5.46 ; \mathrm{L}: 17.89 \pm 6.8 \\
\text { Content } 49.33\end{array}$ & $\begin{array}{l}\text { Diameter } 11.57 \pm 1.88 \\
\text { Content } 2.67\end{array}$ \\
\hline Laetiporus montanus & $\begin{array}{l}\text { W: } 9.79 \pm 2.65 ; \mathrm{L}: 12.62 \pm 3.26 \\
\text { Content } 56.67\end{array}$ & $\begin{array}{l}\text { W: } 12.32 \pm 4.05 ; \mathrm{L}: 18.15 \pm 6.23 \\
\text { Content } 27.33\end{array}$ & $\begin{array}{l}\text { Diameter } 9.57 \pm 1.7 \\
\text { Content } 16\end{array}$ \\
\hline Pleurotus citrinopileatus & $\begin{array}{l}\text { W: } 12.1 \pm 4.79 ; \mathrm{L}: 16.28 \pm 6.87 \\
\text { Content } 41\end{array}$ & $\begin{array}{l}\text { W: } 13.19 \pm 5.52 ; \mathrm{L}: 17.87 \pm 7.68 \\
\text { Content } 59\end{array}$ & Not found \\
\hline Formitopsis cajanderi & $\begin{array}{l}\text { W: } 16.34 \pm 8.94 ; \text { L: } 20.28 \pm 11.46 \\
\text { Content } 33.6\end{array}$ & $\begin{array}{l}\text { W: } 16.82 \pm 6 ; \text { L: } 24.21 \pm 10.38 \\
\text { Content } 55.2\end{array}$ & $\begin{array}{l}\text { Diameter } 15.79 \pm 3.83 \\
\text { Content } 11.2\end{array}$ \\
\hline Formitopsis pinicola & $\begin{array}{l}\text { W: } 15.73 \pm 12.26 ; \mathrm{L}: 20.38 \pm 16.38 \\
\text { Content } 46.6\end{array}$ & $\begin{array}{l}\text { W: } 17.65 \pm 6.94 ; \mathrm{L}: 22.46 \pm 8.98 \\
\text { Content } 44.2\end{array}$ & $\begin{array}{l}\text { Diameter } 12.19 \pm 3.16 \\
\text { Content } 9.2\end{array}$ \\
\hline Mycorrbaphium adustum & $\begin{array}{l}\text { W: } 14.76 \pm 5.02 ; \mathrm{L}: 19.6 \pm 7.18 \\
\text { Content } 52.3\end{array}$ & $\begin{array}{l}\text { W: } 15.35 \pm 4.17 \text {; L: } 20.40 \pm 5.88 \\
\text { Content } 45\end{array}$ & $\begin{array}{l}\text { Diameter } 17.58 \pm 2.08 \\
\text { Content } 2.7\end{array}$ \\
\hline Trametes versicolor & $\begin{array}{l}\text { W: } 13.72 \pm 6.2 ; \mathrm{L}: 17.21 \pm 6.23 \\
\text { Content } 56.4\end{array}$ & $\begin{array}{l}\text { W: } 13.58 \pm 4.35 ; \mathrm{L}: 17.70 \pm 5.07 \\
\text { Content } 42.8\end{array}$ & $\begin{array}{l}\text { Diameter } 9.59 \\
\text { Content } 0.8\end{array}$ \\
\hline Ganoderma applanatum & $\begin{array}{l}\text { W: } 14.7 \pm 4.43 ; \mathrm{L}: 17.23 \pm 5.47 \\
\text { Content } 40.8\end{array}$ & $\begin{array}{l}\text { W: } 15.40 \pm 4.17 ; \mathrm{L}: 21.02 \pm 6.82 \\
\text { Content } 51.1\end{array}$ & $\begin{array}{l}\text { Diameter } 14.6 \pm 5.84 \\
\text { Content } 8.1\end{array}$ \\
\hline Stereum ostrea & $\begin{array}{l}\text { W: } 16 \pm 8.42 ; \mathrm{L}: 20.25 \pm 10.63 \\
\text { Content } 34.4\end{array}$ & $\begin{array}{l}\text { W: } 15.71 \pm 6.66 ; \mathrm{L}: 20 \pm 7.5 \\
\text { Content } 49.6\end{array}$ & $\begin{array}{l}\text { Diameter } 13.64 \pm 4.74 \\
\text { Content } 16\end{array}$ \\
\hline Trichaptum biforme & $\begin{array}{l}\text { W: } 10.06 \pm 2.92 ; \mathrm{L}: 13.23 \pm 3.91 \\
\text { Content } 38.2\end{array}$ & $\begin{array}{l}\text { W: } 12.82 \pm 3.74 ; \text { L: } 16.43 \pm 4.99 \\
\text { Content } 54.9\end{array}$ & $\begin{array}{l}\text { Diameter } 14.73 \pm 4.16 \\
\text { Content } 6.9\end{array}$ \\
\hline \multicolumn{4}{|l|}{ Trees } \\
\hline Betula platbyphylla, bark & $\begin{array}{l}\text { W: } 12.33 \pm 6.2 ; \mathrm{L}: 15.12 \pm 6.69 \\
\text { Content } 42.2\end{array}$ & $\begin{array}{l}\text { W: } 13.57 \pm 3.95 ; \mathrm{L}: 16.48 \pm 4.92 \\
\text { Content } 41.5\end{array}$ & $\begin{array}{l}\text { Diameter } 19.14 \pm 8.19 \\
\text { Content } 16.3\end{array}$ \\
\hline Betula plathyphylla, wood & $\begin{array}{l}\text { W: } 13.1 \pm 5.42 ; \mathrm{L}: 17.1 \pm 7.15 \\
\text { Content } 49.9\end{array}$ & $\begin{array}{l}\text { W: } 16.16 \pm 6.95 ; \mathrm{L}: 20.36 \pm 8.65 \\
\text { Content } 47\end{array}$ & $\begin{array}{l}\text { Diameter } 23.88 \pm 3.33 \\
\text { Content } 3.1\end{array}$ \\
\hline Quercus mongolica, bark & $\begin{array}{l}\text { W: } 10.75 \pm 4.24 ; \text { L: } 13.44 \pm 4.43 \\
\text { Content } 51.5\end{array}$ & $\begin{array}{l}\text { W: } 11.45 \pm 3.96 ; \text { L: } 14.37 \pm 4.42 \\
\text { Content } 38.6\end{array}$ & $\begin{array}{l}\text { Diameter } 9.93 \pm 3.11 \\
\text { Content } 9.9\end{array}$ \\
\hline Quercus mongolica, wood & $\begin{array}{l}\text { W: } 12.53 \pm 6.79 ; \mathrm{L}: 13.21 \pm 6.97 \\
\text { Content } 34\end{array}$ & $\begin{array}{l}\text { W: } 17.47 \pm 8.42 ; \text { L: } 16.4 \pm 7.2 \\
\text { Content } 57.33\end{array}$ & $\begin{array}{l}\text { Diameter } 16.99 \pm 9.95 \\
\text { Content } 8.67\end{array}$ \\
\hline Salix sp., bark & $\begin{array}{l}\text { W: } 11.44 \pm 3.81 ; \mathrm{L}: 14.3 \pm 4.83 \\
\text { Content } 48\end{array}$ & $\begin{array}{l}\text { W: } 10.79 \pm 2.58 ; \mathrm{L}: 14.22 \pm 3.04 \\
\text { Content } 48.67\end{array}$ & $\begin{array}{l}\text { Diameter } 13.37 \pm 1.95 \\
\text { Content } 3.33\end{array}$ \\
\hline Salix sp., wood & $\begin{array}{l}\text { W: } 14.92 \pm 4.07 ; \mathrm{L}: 19.44 \pm 6.4 \\
\text { Content } 51.34\end{array}$ & $\begin{array}{l}\text { W: } 24.34 \pm 10.21 ; \mathrm{L}: 29.47 \pm 10.8 \\
\text { Content } 45.33\end{array}$ & $\begin{array}{l}\text { Diameter } 16.33 \pm 5.6 \\
\text { Content } 3.33\end{array}$ \\
\hline Larix daburica, bark & $\begin{array}{l}\text { W: } 7.69 \pm 3.21 ; \mathrm{L}: 10.17 \pm 4.41 \\
\text { Content } 59.33\end{array}$ & $\begin{array}{l}\text { W: } 9.59 \pm 3.38 ; \mathrm{L}: 12 \pm 3.7 \\
\text { Content } 40\end{array}$ & $\begin{array}{l}\text { Diameter } 5.523438 \\
\text { Content } 0.67\end{array}$ \\
\hline Larix daburica, wood & $\begin{array}{l}\text { W: } 21.91 \pm 9.48 ; \mathrm{L}: 28.03 \pm 12.92 \\
\text { Content } 26\end{array}$ & $\begin{array}{l}\text { W: } 28.27 \pm 11.74 ; \mathrm{L}: 35.17 \pm 14.6 \\
\text { Content } 60.67\end{array}$ & $\begin{array}{l}\text { Diameter } 22.4 \pm 8.13 \\
\text { Content } 13.33\end{array}$ \\
\hline Alnus hirsuta, bark & $\begin{array}{l}\text { W: } 13.53 \pm 7.25 ; \mathrm{L}: 17.38 \pm 9.02 \\
\text { Content } 50\end{array}$ & $\begin{array}{l}\text { W: } 17.4 \pm 7.68 ; \mathrm{L}: 22.68 \pm 11.72 \\
\text { Content } 44\end{array}$ & $\begin{array}{l}\text { Diameter } 12.58 \pm 3.09 \\
\text { Content } 6\end{array}$ \\
\hline Alnus birsuta, wood & $\begin{array}{l}\text { W: } 11.6 \pm 4.54 ; \mathrm{L}: 14.79 \pm 6.03 \\
\text { Content } 46.67\end{array}$ & $\begin{array}{l}\text { W: } 13.26 \pm 6.46 ; \text { L: } 17.33 \pm 7.55 \\
\text { Content } 36.67\end{array}$ & $\begin{array}{l}\text { Diameter } 11.88 \pm 3.69 \\
\text { Content } 16.63\end{array}$ \\
\hline
\end{tabular}

Remarks: W - width, L - length 